\title{
Ekmeklik Buğdayda (Triticum aestivum L.) Zeleny Sedimantasyon Analizi ve Diğer Kalite Paramatreleri ile İlişkisinin İncelenmesi
}

\author{
Alaettin KEÇELII $\dot{I}^{1} \quad$ Asuman KAPLAN EVLICEE ${ }^{2} \quad$ Aliye PEHLIVAN $^{2} \quad$ Turgay ŞANAL $^{2}$, \\ Kazım KARACA $^{2} \quad$ Seda KÜLEN ${ }^{2}$ Asiye SEIS SUBAŞI ${ }^{2} \quad$ Ayten SALANTUR $^{2}$ \\ ${ }^{1}$ Pamukkale Üniversitesi Uygulamalı Bilimler Yüksekokulu Organik Tarım İşletmeciliği Bölümü \\ ${ }^{2}$ Tarla Bitkileri Merkez Araştırma Enstitüsü Müdürlüğü-Ankara \\ $\triangle$ : alaettink@pau.edu.tr
}

Geliş (Received): 04.11.2017

Kabul (Accepted): 15.12.2017

\begin{abstract}
ÖZET: Bu çalışmada, ekmeklik buğday genotiplerinde fiziksel, kimyasal ve reolojik kalite özellikleri incelenmiştir. Islahın erken kademesinde materyal miktarı yetersiz olduğu için kalitenin belirlenmesinde Zeleny sedimantasyon analizi önem kazanmaktadır. Çalışmada, Zeleny sedimantasyon değeri ile diğer kalite parametreleri arasındaki ilişki değerlendirilmiştir. 2015-2016 Yetiştirme sezonunda sulu koşullarda 4 lokasyonda kurulan denemelerden elde edilen materyal kullanılmıştır.1000 tane ağırlığı, hektolitre ağırlığı, tanede protein miktarı, un verimi, yaş gluten, kuru gluten ve gluten indeksi, alveograf parametreleri (G, P, L, P/G, P/L ve W), Zeleny sedimentasyon ve beklemeli Zeleny sedimantasyon değerleri, farinograf parametreleri (su absorbsiyonu ve yumuşama değeri) ile glutograf değerleri (stretch $\mathrm{s}$, stretch BU ve relaxation BU) değerleri belirlenmiştir. Zeleny sedimantasyon değerleri ile aralarındaki korelasyonlar incelenmiştir. Araştırma sonucunda; Zeleny sedimantasyon değeri ile alveograf (G, L, P ve W), beklemeli Zeleny sedimantasyon değeri, farinograf su absorbsiyonu, tanede protein, yaş gluten ve kuru gluten değerleri $(p<0,01)$, glutograf stretch $(s)$ ve un verimi $(p<0,05)$ arasında pozitif; farinograf yumuşama değeri arasında negatif $(\mathrm{p}<0,01)$ korelasyon değerleri elde edilmiştir. Zeleny sedimantasyon değeri ile yüksek korelasyon değerlerine sahip kalite parametreleri arasındaki regresyon incelendiğinde, en yüksek belirtme katsayısına (R2) sahip regresyon eşitlikleri alveograf enerji değeri $(\mathrm{W})$, tanede protein ve kuru gluten parametrelerinden elde edilmiştir.
\end{abstract}

Anahtar kelimeler: ekmeklik buğday, kalite, regresyon, korelasyon, zeleny sedimentasyon

\section{Investigation of the relationship between Zeleny Sedimentation Analysis and Other Quality Parameters in Bread Wheat (Triticum aestivum L.)}

\begin{abstract}
In this research physical, chemical and rheological quality properties were examined in bread wheat genotypes. In early generation of plant breeding due to the material inadequacy, Zeleny sedimentation analyze is important in order to determine the quality. In this study, relationship between Zeleny sedimentation value and other quality parameters were investigated. Material was obtained from trials which were carried out in four locations on irrigated conditions in 2015-2016 growing season.Thousand kernel weight, test weight, grain protein content, flour yield, wet gluten, dry gluten and gluten index, alveograph parameters (G, P, L, P/G, P/L and W), Zeleny sedimentation and modified Zeleny sedimentation values, farinograph parameters (water absorption and softening degree) and glutograph values (stretch s, stretch BU and relaxation BU) were determined. Correlation coefficients between Zeleny sedimentation values and these parameters were investigated.Results showed that positive correlation coefficients were found between Zeleny sedimentation value and alveograph parameters $(\mathrm{G}, \mathrm{L}, \mathrm{P}$ and $\mathrm{W})$, modified Zeleny sedimentation value, farinograph water absorption, grain protein content, wet gluten and dry gluten contents $(\mathrm{p}<0,01)$, glutograph stretch $(\mathrm{s})$ and flour yield $(\mathrm{p}<0.05)$; negative correlation coefficients were obtained between Zeleny sedimentation value and farinograph softening degree $(\mathrm{p}<0,01)$. By examining the regressions between the Zeleny sedimentation value and the quality parameters with high correlation coefficient values, regression equations of highest determination coefficients (R2) were obtained from alveograph energy value $(\mathrm{W})$, grain protein content and dry gluten parameters with the from.

Keywords: bread wheat, quality parameters, regression, correlation coefficients, zeleny sedimentation
\end{abstract}

\section{GIRİŞ}

Toprak Mahsulleri Ofisi’nin “Türkiye'de Ekmek İsrafı “ üzerine yaptırdığı araştırma sonuçlarına göre günlük 25.295 ton, yıllık ise 9.2 milyon ton ekmek üretildiği bildirilmiştir (TMO 2013). Dünya'da olduğu gibi ülkemizde de temel besin maddesi olarak ekmek kullanımının yüksek olması aynı zamanda geleneklerimizden gelen beslenme kültürüne de bağlıdır. Artan nüfusun beslenmesinin yeterli düzeyde sağlanması temelde ekmek üretimi ile başlamaktadır. İklim ve ekolojik özelliklerinden dolayı geniş bir ürün yelpazesi sağlayan ve tarımsal üretim açısından avantajlı olan ülkemizin, kendi kendine yetebilmesi açısından iyi durumda olduğu söylenebilir. Toplam istihdamın yaklaşık \%21'lik bir kısmı, tarım sektöründe yer almaktadır. Tarım yapılabilir alan (23,9 m.h.) içerisinde $\% 49$ ile en büyük payı tahıllar almakta ve bu alanları içerisinde ise \%67'lik pay ile ilk sırada buğday yer almaktadır (TÜİK 2016).

Günümüzde, tüketici ihtiyaçları doğrultusunda ürün yelpazesini genişleten sanayici istenilen son ürün kalitesine göre farklı kalite özelliklerine sahip buğday 
talebinde bulunmaktadır. Her ne kadar kalite kavramı; üretici, sanayi, firıncı ve tüketiciye göre farklı anlamlar ifade etse de optimum değerlere sahip buğday temini, bu amaca yönelik çalışan ıslahçı açısından farklı kalite özelliklerine sahip buğday ıslahı bir gereklilik haline gelmiştir. Hem klasik melezleme 1slahında hem de marker destekli seleksiyon islahında son ürüne yönelik kaliteyi barındıracak çeşit ıslahı önemini giderek arttırmaktadır.

Fiziksel, kimyasal ve reolojik analiz yöntemleri kullanılarak belirlenen buğday kalitesi son üründe ortaya çıkmaktadır. Erken kademe materyallerinde başlanılan kalite belirleme çalışmalarını kısıtlayan en büyük faktör yeterli miktarda buğday numunesi olmaması ve çok sayıda hattın bu çalışmalarda yer almasıdır. İleri kademe materyallerinde yapılan analizler daha detaylı ve kaliteyi belirlemeye yönelik daha fazla parametre içermesine karşılık erken kademede özellikle ön verim denemelerinde ki fazla sayıda materyalin hızlı bir şekilde değerlendirilerek ileri kademeye aktarılacak materyalin belirlenmesi gerekmektedir. $\mathrm{Bu}$ sebeple yapılacak analizlerin hılı ve güvenilir olması gereklidir. Bu çalışmada Zeleny sedimantasyon ile diğer kalite parametreleri arasındaki korelasyon ve regresyon değerleri incelenmiş ve Zeleny sedimantasyon analizinin buğday islahında kalite belirlenmesinde erken kademede ki kullanımının güvenilirliği test edilmiştir.

\section{MATERYAL ve YÖNTEM}

Çalışmada 2015-2016 yetiştirme sezonunda 4 lokasyonda (Edirne, Eskişehir, Ankara, Erzurum) ekilen denemelere ait 11 Çeşit ve 13 hat kullanılmıştır. Buğday numuneleri öncelikle (Quator, Tripette\&Renaud) dokaj ünitesinde kırık ve diğer mekanik karışıklardan temizlenerek hektolitre (Vasilijek ve Banasik, 1980) ve bin tane ağırlıkları (Köksel ve ark. 2000) belirlenmiştir. Tane protein oranı Dumas Yöntemi ile NDA 701 Dumas Nitrogen Analyzer cihazı kullanılarak AACC metot no: 46-30 (Anonymous 2000)'a göre tespit edilmiş, NIT (Foss Infratec 1241 Grain Analyzer) cihazı ile rutubet oranı belirlenen buğday numuneleri tavlanarak laboratuar tipi değirmende (Buhler MLU 202) AACC metot no: 26-21A (Anonymous 2000)'ya göre öğütülerek reolojik analizlere hazır hale getirilmişlerdir. Elde edilen un örneklerinde ICC standart no: 116/1 (Anonymous 2008)'e göre Zeleny sedimantasyon, (Atlı ve ark. 1988)'e göre ise beklemeli Zeleny sedimantasyon değerleri elde edilmiştir. Chopin alveograf cihazı kullanılarak alveograf özellikleri (P, L, G, W) AACC metot no: 54-50 (Anonymous 2000)'ye göre, farinograf özellikleri (su absorbsiyon, yumuşama değeri, stabilite, gelişme süresi) ise Farinograph-E cihazı kullanılarak AACC metot no: 54-21 (Anonymous 2000)' e göre belirlenmiştir. Yaş gluten miktarı ve gluten indeksi AACC metot no: 38-21A (Anonymous 2000)'ya göre, kuru gluten miktarı ise Özkaya ve Özkaya (2005a)' ya göre belirlenmiştir. Elde edilen yaş glutenin "stretch ve relaxation değerleri Brabender Glutograph-E (Duisburg, Almanya) cihazı kullanılarak (Anonymous 2005)'e göre belirlenmiştir. Sonuçların değerlendirilmesi JMP 7.0 istatistik paket programı kullanılarak yapılmıştır.

\section{BULGULAR ve TARTIŞMA}

$\mathrm{Bu}$ çalışmada yer alan hat ve çeşitlere ait sonuçlar ayrı ayrı değerlendirilerek, bu hat ve çeşitlere ait en yüksek ve en küçük değer, standart sapma ve ortalama değerler Çizelge 1'de Zeleny sedimantasyon değeri ile diğer kalite parametreleri arasındaki korelasyon değerleri ise Çizelge 2'de verilmiştir.

Çizelge 1. Çeşit ve hatlara ait ortalama, standart sapma, en düşük ve en yüksek kalite değerleri

\begin{tabular}{|c|c|c|c|c|c|c|c|c|}
\hline \multirow{2}{*}{ Analiz Adı/ Değer } & \multicolumn{2}{|c|}{ ORTALAMA } & \multicolumn{2}{|c|}{ STANDART } & \multicolumn{2}{|c|}{ EN DÜŞÜK } & \multicolumn{2}{|c|}{ EN YÜKSEK } \\
\hline & Çeșit & Hat & Çeșit & Hat & Çeșit & Hat & Çeșit & Hat \\
\hline Hektolitre Ăğırlığı (kg/hl) & 78,6 & 79,4 & 2,4 & 2,1 & 73,5 & 73,6 & 84,0 & 84,0 \\
\hline 1000 Tane Ağırlığı (g) & 35,8 & 35,7 & 3,7 & 3,9 & 27,2 & 28,6 & 41,4 & 44,7 \\
\hline Un Verimi (\%) & 64,6 & 65,2 & 5,8 & 5,0 & 46,9 & 52,9 & 72,0 & 73,4 \\
\hline Tane Proteini (\%) & 12,6 & 12,7 & 2,4 & 2,5 & 8,1 & 8,1 & 16,8 & 16,8 \\
\hline Zeleny Sedimantasyon (ml) & 35 & 35,4 & 10 & 10,1 & 15 & 19,0 & 61 & 61,0 \\
\hline Beklemeli Zeleny Sedim. (ml) & 45 & 47,3 & 12 & 13,4 & 22 & 21,0 & 66 & 71,0 \\
\hline Alveograf P (mm) & 97 & 106,8 & 31 & 31,6 & 18 & 42,0 & 152 & 172 \\
\hline Alveograf $L(\mathbf{m m})$ & 50 & 45,6 & 20 & 19,3 & 19 & 17,0 & 124 & 120 \\
\hline Alveograf $G$ & 15,4 & 14,7 & 2,7 & 3,0 & 9,7 & 9,2 & 24,8 & 24,4 \\
\hline Alveograf W (10 ${ }^{-4}$ Joule $)$ & 176 & 179 & 66 & 61 & 21 & 76 & 338 & 381 \\
\hline Alveograf $P / G$ & 6,6 & 7,8 & 2,7 & 3,5 & 1,5 & 2,3 & 14,5 & 17,9 \\
\hline Alveograf $P / L$ & 2,3 & 2,9 & 1,3 & 1,9 & 0,6 & 0,6 & 7,4 & 9,6 \\
\hline Faringograf Absorpsiyon (\%) & 58,7 & 59,4 & 4,3 & 3,7 & 46,6 & 50,7 & 66,4 & 66,8 \\
\hline Farinograf Yumușama Derecesi & 49 & 58,4 & 36 & 46,3 & 10 & 0,0 & 131 & 201 \\
\hline Yaș Gluten (\%) & 28,8 & 27,9 & 7,1 & 7,2 & 11,3 & 13,3 & 42,5 & 45,2 \\
\hline Kuru Gluten (\%) & 9,6 & 9,3 & 2,4 & 2,4 & 3,7 & 4,4 & 13,7 & 14,2 \\
\hline Gluten İndeksi (\%) & 85 & 84 & 13 & 16 & 43 & 36 & 99 & 100 \\
\hline Glutograf Stretch (BU) & 675 & 651 & 119 & 152 & 390 & 277 & 811 & 811 \\
\hline Glutograf Stretch (s) & 101 & 102 & 36 & 37 & 13 & 10 & 125 & 125 \\
\hline Glutograf Relaxation (BU) & 564 & 544 & 92 & 119 & 328 & 261 & 679 & 700 \\
\hline
\end{tabular}


Çalışmamızda elde edilen protein değerleri \%8,116,8 arasında değişim göstermiş olup (Çizelge 1) bu konuda daha önce yapılan ve protein miktarının tür ve çeşide bağlı olmakla birlikte çevre ve iklim koşullarına bağlı olarak \%6-20 arasında değiştiğini bildiren çalışma ile benzerlik göstermektedir (Özkaya\&Özkaya 2005b). Protein oranı ile Zeleny sedimantasyon değeri arasında $\left(r=0,6247^{* *}\right)$ pozitif bir ilişki belirlenmiştir (Çizelge 2). Yapılan benzer çalışmalarda da Zeleny sedimantasyon değeri ile protein oranı arasında pozitif ve \%0,01 düzeyinde önemli korelasyonlar tespit edilmiştir (Dwyer et. al., 1982; Castille and Vandam, 1985; Branlard and Dardenet, 1985; Biston et. al., 1986; Garcia et. al., 1989; Hruskova and Famera, 2003).

Yüksek un verimi sanayi tarafından istenen bir özelliktir. Ancak verim değeri arttıkça una geçen kepek miktarını da arttıracağından ekmek yapımı esnasında unun içindeki bu kepekler fermentasyon sırasında mikroorganizmaların şeker tüketimi sonucu ortaya çıkardığı ve hacimli ekmek yapısının oluşmasında önemli olan $\mathrm{CO}_{2}$ gazının tutulumunu azalttığı için istenmeyen bir durumdur. Çalışmamızda un verim değerleri \%46,9-73,3 arasında değişim göstermiş olup hat ve çeșitlere ait ortalama değerler sırasıyla $\% 65,2$ ve \%64,6 olarak birbirine yakın olarak tespit edilmiștir (Çizelge 1). Ekim sisteminin buğday tane ve un özelliklerine olan etkilerinin araștırıldığı bir çalışmada (Varga et. al., 2003) Zeleny sedimantasyon değeri ile un verimi arasında bir ilișki saptanmamış olmasına rağmen bulgularımız un verimi ile Zeleny sedimantasyon değeri arasinda $\left(\mathrm{r}=0,2057^{*}\right)$ pozitif bir korelasyon olduğunu göstermiştir (Çizelge 2). Bu durumun kepeğin undan daha fazla çözelti absorblama özelliğinden kaynaklandığı düşünülmektedir.

Çizelge 2. Zeleny sedimantasyon değeri ile diğer kalite parametreleri arasındaki korelasyon ve ihtimal değerleri

\begin{tabular}{|c|c|c|c|c|c|}
\hline Değişken & $\begin{array}{c}\text { Korelasyon } \\
\text { Değeri }\end{array}$ & $\begin{array}{l}\text { İhtimal } \\
\text { Değeri }\end{array}$ & Değişken & $\begin{array}{l}\text { Korelasyon } \\
\text { Değeri }\end{array}$ & $\begin{array}{l}\text { İhtimal } \\
\text { Değeri }\end{array}$ \\
\hline 1000 Tane Ağırlığı (g) & $-0,1227$ & 0,2335 & Gluten İndeksi (\%) & 0,1708 & 0,0961 \\
\hline Alveograf G & 0,4448 & $<, 0001$ & Glutograf Relaxation (BU) & $-0,112$ & 0,2772 \\
\hline Alveograf L (mm) & 0,4351 & $<, 0001$ & Glutograf Stretch (BU) & $-0,1374$ & 0,1818 \\
\hline Alveograf P (mm) & 0,2638 & 0,0094 & Glutograf Stretch (s) & 0,2027 & 0,0477 \\
\hline Alveograf P/G & $-0,0019$ & 0,9854 & Hektolitre Ağırlığ 1 NIT(kg/hl) & 0,0397 & 0,701 \\
\hline Alveograf P/L & $-0,1135$ & 0,271 & Kuru Gluten (\%) & 0,5747 & $<, 0001$ \\
\hline Alveograf W (10-4 Joule) & 0,709 & $<, 0001$ & Tane Proteini Dumas (\%) & 0,6247 & $<, 0001$ \\
\hline Beklemeli Zeleny Sedim. (ml) & 0,8586 & $<, 0001$ & Un Verimi (\%) & 0,2057 & 0,0443 \\
\hline Faringograf Absorpsiyon (\%) & 0,3811 & 0,0001 & Yaş Gluten (\%) & 0,5373 & $<, 0001$ \\
\hline Farinograf Yumuşama Derecesi (BU) & $-0,3013$ & 0,003 & & & \\
\hline
\end{tabular}

Viskoelastik bir yapıya sahip olan hamurun şişmeye karșı direncinin ölçüldüğü alveograf analizinden elde edilen enerji değeri (W) fermentasyon esnasında mikroorganizmalar tarafindan açığa çıarılan $\mathrm{CO}_{2}$ gazının tutulumum miktarını belirlediği için ekmek yapımında ekmeğin hacmi ve ekmek içyapısı üzerine önemli bir etkiye sahiptir. Alveograf enerji değerleri 21$381 \mathrm{~J}$. arasında değişim göstermiş olup hat ve çeşit ortalamaları birbirine yakın sonuçlar vermişlerdir (176179 J.). Calıșmamızda Zeleny sedimantasyon değeri ile alveograf enerji değeri arasında $(r=0,709 * *)$ pozitif ve yüksek bir korelasyon olduğu belirlenmiştir. Bu konuda daha önce yapilan (Surma et. al. 2012) tarafindan yapılan ve \%0,01 düzeyinde korelasyon olduğu belirlenen çalışma ile benzerlik göstermektedir.

Unun belli bir konsistense sahip hamur olabilmesi için ilave edilecek su miktarını veren farinograf su absorbsiyon değeri ve unun ekmeklik, düz ekmek (lavaş vb.) veya bisküvilik özelliğe sahip olup olmadığının belirlendiği farinograf yumuşama değerleri sırasılyla hat ve çeșitlerde \%46,6-66,8 ve $0-210$ BU olarak tespit edilmiştir. Farinograf absorbsiyon ortalama değerleri hat ve çeşitlerde $(\% 58,7-59,4)$ birbirine yakın olarak ölçülmüştür. Yumuşama değerleri de ekmeklik kalitesi için olması gereken sinırlarda belirlenmiștir. $\mathrm{Bu}$ çalışmada Zeleny sedimantasyon ile farinograf absorbsiyon değeri arasında $\left(\mathrm{r}=0,3811^{* *}\right)$ pozitif ve yüksek bir korelasyon, yumușama değeri ile arasında ise negatif $\left(r=-0,3013^{*}\right)$ bir korelasyon hesaplanmıștır. Aydoğan ve ark. 2015 tarafindan yapılan ve absorbsiyon değeri ile $\% 0,05$, yumuşama değeri ile negatif ve $\% 0,01$ düzeyinde korelasyon belirlenen çalıșma ile benzer sonuçlara ulaşılmıștır. Buğday proteinlerinden gliadin ve gluteninin su alarak şişmek suretiyle meydana getirdiği elastik bir madde olan gluten miktarı çeşite göre değișmekle birlikte çevre koşullarından ve agronomik uygulamalardan oldukça etkilenen bir özelliktir. Yüksek yaş gluten miktarı sanayi ve firıncılar tarafindan talep görmesine karşlık gluten kalitesinin de iyi olması gerekmektedir. Bu çalışmada yaş gluten miktarları \%11,3-45,2 arasında değișim göstermiş olup, hat ve çeşit ortalamaları birbirine yakın değerler $(\% 27,9-28,8)$ vermişlerdir. Zeleny sedimantasyon değeri ile yas gluten arasında $(\mathrm{r}=0,5373 * *)$ pozitif ve yüksek bir korelasyon tespit edilmiștir. Bu durum Zeleny sedimantasyon ile yaş gluten arasında $\% 0,01$ düzeyinde pozitif korelasyon tespit eden Surma ve ark. (2012) çalışması ile uyumluluk göstermektedir.

Çalışmada Zeleny sedimantasyon ile önemli korelasyon katsayısına sahip diğer özellikler ve Zeleny sedimantasyon değeri arasındaki regresyon incelenmiş ve sonuçlar Çizelge 3 'te verilmiștir. 
Çizelge 3. Zeleny sedimantasyon ile önemli korelasyon değerlerine sahip kalite parametreleri ve Zeleny sedimantasyon değeri arasındaki regresyon modelleri ve belirtme katsayıları

\begin{tabular}{|l|l|}
\hline \multicolumn{1}{|c|}{ Regresyon Modelleri } & \multicolumn{1}{|c|}{ Belirtme Katsayıları $\mathbf{R}^{\mathbf{2}}$} \\
\hline Zeleny Sedimantasyon $=9,8212554+0,3860405^{*}$ Un Verimi & $0,042^{*}$ \\
\hline Zeleny Sedimantasyon $=29,201636+0,0560591 *$ Glutograf Stretch $(\mathrm{s})$ & $0,041^{*}$ \\
\hline Zeleny Sedimantasyon $=2,7507129+2,5557674 *$ Tane Proteini & $0,390 * *$ \\
\hline Zeleny Sedimantasyon $=26,151123+0,0855363^{*}$ Alveograf P & $0,070^{* *}$ \\
\hline Zeleny Sedimantasyon $=24,090595+0,2253444 *$ Alveograf L & $0,190^{* *}$ \\
\hline Zeleny Sedimantasyon $=11,604955+1,546 *$ Alveograf G & $0,198^{* *}$ \\
\hline Zeleny Sedimantasyon $=14,65787+0,1154097^{*}$ Alveograf W & $0,503^{* *}$ \\
\hline Zeleny Sedimantasyon $=-22,62546+0,9736247^{*}$ Faringograf Absorpsiyon & $0,145^{* *}$ \\
\hline Zeleny Sedimantasyon $=38,257498-0,0679981^{*}$ Farinograf Yumuşama D. & $0,091^{* *}$ \\
\hline Zeleny Sedimantasyon $=13,442589+0,7600997 *$ Yaş Gluten & $0,289^{* *}$ \\
\hline Zeleny Sedimantasyon $=12,192856+2,412209^{*}$ Kuru Gluten & $0,330^{* *}$ \\
\hline
\end{tabular}

En yüksek belirtme katsayısına sahip regresyon eşitlikleri alveograf enerji değeri $\left(\mathrm{R}^{2}=0,503^{* *}\right)$ ve tane proteini $\left(\mathrm{R}^{2}=390^{* *}\right)$ parametrelerinden elde edilmiștir. Bunları sirasıyla kuru gluten $\left(\mathrm{R}^{2}=0,330^{* *}\right)$, yaş gluten $\left(\mathrm{R}^{2}=289 * *\right)$, alveograf $\mathrm{G}\left(\left(\mathrm{R}^{2}=198^{* *}\right)\right.$, alveograf $\mathrm{L}$ $\left(\left(R^{2}=190^{* *}\right)\right.$, farinograf absorbsiyon değeri $\left(\mathrm{R}^{2}=0,145^{* *}\right)$, farinograf yumuşama değeri $\left(\mathrm{R}^{2}=0,091^{* *}\right)$, un verimi $\left(\mathrm{R}^{2}=0,042 *\right)$ ve glutograf stretch değeri $\left(\mathrm{R}^{2}=0,041 *\right)$ takip etmiştir.

Denemenin Zeleny sedimantasyon değer ortalaması $41 \mathrm{ml}$ olarak hesaplanmıştır. Ortalamadan yüksek Zeleny değerine sahip hat ve çeşitler diğer kalite parametreleri bakımından da incelendiğinde özellikle HAT-1 tüm hat ve çeşitlerden iyi kalite değerleri göstermiştir. Bunu Bezostaja-1 ve Nevzatbey çeşitleri ve HAT-15 ve HAT-4 takip etmişlerdir.

\section{SONUC}

Çalışma sonucunda Zeleny sedimantasyon değeri ile protein miktarı, un verimi, alveograf parametreleri $(\mathrm{P}$, L, G, W), farinograf su absorbsiyon ve yumuşama değeri, yaș gluten, kuru gluten, glutograf stretch değeri, arasında önemli korelasyonlar saptanmıştır. İleri kademede yapılan analizler (Alveograf ve farinograf parametreleri) numune azlığı ve fazla zamana ihtiyaç duyulması ile erken kademe islah materyallerinin kalitesinin belirlenmesinde kullanılamamaktadır. $\mathrm{Bu}$ çalışma sonucu göstermiştir ki erken kademe islah materyallerinin kalitesinin belirlenmesinde yoğun olarak kullanılan Zeleny sedimantasyon analizi hızlı sonuçlar vermektedir ve son ürün kalitesinin belirlenmesinde güvenilir bir şekilde kullanılabilir.

\section{KAYNAKLAR}

Anonymous 2000. American Association of Cereal Chemists, Approved Methods of the AACC, 10th ed., The Association:. Methods No: 46-30, 54-50, 54-21, 38-21A, 26-21A. St. Paul MN, USA

Anonymous 2005. Instruction Manual Glutograph-E, Brabender Measurement and Control Systems.
Brabender GmbH\&Co.KG. Kulturstr. 51-55. 47055 Duisburg. Germany

Anonymous 2008. Standard Methods of International Association for Cereal Science and Technology (ICC), Vienna, Austria

Atlı A, Koksel H, Dağ A 1988. Unda Sune ve Kımıl Zararının Belirlenmesi İcin Geliştirilen Yontemler ve $\mathrm{Bu}$ Yontemlerin Uygulanabilirliği Üzerine Araştırmalar. Tarla Bitkileri Merkez Enstitusu Yayınları, No: 3

Aydoğan S, Şahin M, Akçacık AG, Hamzaoğlu S, Taner S 2015. Relationships between Farinograph Parameters and Bread Volume, Physicochemical Traits in Bread Wheat Flours. Journal of Bahri Dagdas Crop Research 3 (1):14-18

Branlard G, Dardevet M 1985. Diversity of Grain Proteins and Bread Wheat Quality. Correlation Between Gliadin Bands and Flour Quality Characteristics. J Cereal Sci, 3: P:329

Biston R, Castille JP, Crohain A, Dardenne P, Falise A, Frankinet M, Herman JL, Monfort B, Noulard R, Rixhon L 1986. Qualite et Teneur en Proteines des Bles. Note Technique C. R. A. Glemboux, No: 6/40

Castille JP, Vandam JB 1985. L'influence du Facteur Variete sur La Qualite. In 'Qualite et Teneur en Proteines des Bles. Note Technique C. R. A. Et F. S. A, Gembloux, 6/40, 5

Dwyer E, Walshe T, Gormley TR 1982. Some Aspect of The Quality of Spring Wheat Grown in Ireland, 1975-1979. Ir. J. Fd. Sci. Tech., 6: 79

Garcia, A, Garcia B, Blanco M 1989. Variability and Relationship Between Protein and Zeleny Sedimentation Value in Wheat Varieties. Agrochimica, 33(6): 423-433. Spain.

Hruskova M, Famera O 2003. Prediction of Wheat and Flour Zeleny Sedimentation Value Using NIR Technique. Czech J Food Sci, 21 (3): 91-96

Koksel H, Sivri D, Ozboy O, Başman A, Karacan HD 2000. Tahil Laboratuarı El Kitabı. Hacettepe Universitesi Muhendislik Fak, Yayınları No: 47 
Ozkaya B, Ozkaya H 2005a. Tahıl Urunleri Analiz Yontemleri. Gıda Teknolojisi Derneği Yayınları No:14

Ozkaya H, Ozkaya B 2005b. Oğutme Teknolojisi. Gıda Teknolojisi Derneği Yayınları No:30

Surma M, Adamski T, Banaszak Z, Kaczmarek Z, Kuczynska H, Majcher M, Ługowska B, Obuchowski W, Salmanowicz B, Krystkowiak K 2012. Effect of Genotype, Environment and Their Interaction on Quality Parameters of Wheat Breeding Lines of Diverse Grain Hardness. Plant Prod Sci, 15(3): 192-203

TÜIKK 2016. https://www.tuik.gov.tr/ Son Erişim 30.08.2017 13:46

TMO 2013. Türkiye'de Ekmek İsrafı Araştırması
TMO 2016. 2016 Y1lı Hububat Raporu

Unal S 2002. Buğdayda Kalitenin Önemi ve Belirlenmesinde Kullanılan Yöntemler. Hububat Urunleri Teknolojisi Kongre ve Sergisi, 3-4 Ekim 2002 Gaziantep, 25-37

Varga B, Svecnjak Z, Jurkovic Z, Kovacevic J, Jukic Z 2003. Wheat Grain and Flour Quality as Affected by Cropping Intensity. Food Technol Biotechnol, 41(4):321-329.

Vasiljevic S, Banasik OJ 1980. Quality Testing Methods for Durum Wheat and Its Products. Department of Cereal Chemistry and Technology, North Dakota State University, 134 p, Fargo, North Dakota. 